\title{
The prophylactic effect of dexamethasone on postoperative sore throat in prone position surgery
}

\author{
Sang Ho Lee, Yoon Chan Lee, Ji Hyeon Lee, So Ron Choi, Seung-Cheol Lee, \\ Jong Hwan Lee, and Chan Jong Chung
}

Department of Anesthesiology and Pain Medicine, Dong-A University Hospital, Busan, Korea

Background: Sore throat and hoarseness are common complications after general anesthesia with tracheal intubation. The position for patients can affect the incidence of postoperative sore throat (POST) by causing displacement of the endotracheal tube. This study investigated the prophylactic effect of dexamethasone in prone position surgeries.

Methods: One hundred-fifty patients undergoing lumbar spine surgery (18-75 yr) were randomly allocated into the normal saline group (group $\mathrm{P}, \mathrm{n}=50$ ), dexamethasone $0.1 \mathrm{mg} / \mathrm{kg}$ group (group $\mathrm{D} 1, \mathrm{n}=50$ ) or dexamethasone $0.2 \mathrm{mg} / \mathrm{kg}$ group (group D2, $\mathrm{n}=50$ ). The incidence and severity of POST, hoarseness, and cough were measured using direct interview at 1,6 , and $24 \mathrm{~h}$ after tracheal extubation. The severity of POST, hoarseness, and cough were graded using a 4-point scale.

Results: At 1, 6, and $24 \mathrm{~h}$ after extubation, the incidence of sore throat was significantly lower in group D1 ( $1 \mathrm{~h} ; \mathrm{P}=0.015$, $6 \mathrm{~h} ; \mathrm{P}<0.001,24 \mathrm{~h} ; \mathrm{P}=0.038)$ and group $\mathrm{D} 2(1 \mathrm{~h} ; \mathrm{P}<0.001,6 \mathrm{~h} ; \mathrm{P}<0.001,24 \mathrm{~h} ; \mathrm{P}=0.017)$ compared to group $\mathrm{P}$. There were less number of patients in the groups D1 and D2 than group P suffering from moderate grade of POST at 1, $24 \mathrm{~h}$ after extubation. The incidence of hoarseness at 1,6 , and $24 \mathrm{~h}$ after extubation was significantly lower in groups D2 than group $\mathrm{P}(\mathrm{P}<0.001)$. There were no significant differences in the incidence of cough among the three groups.

Conclusions: The prophylactic use of dexamethasone $0.1 \mathrm{mg} / \mathrm{kg}$ and $0.2 \mathrm{mg} / \mathrm{kg}$ in prone surgery reduces the incidence of postoperative sore throat and dexamethasone $0.2 \mathrm{mg} / \mathrm{kg}$ decreases the incidence of hoarseness.

Key Words: Cough, Dexamethasone, Hoarseness, Prone position, Sore throat.

Corresponding author: Ji Hyeon Lee, M.D., Ph.D.

Department of Anesthesiology and Pain Medicine, Dong-A University

Medical Center, 26, Daesingongwon-ro, Seo-gu, Busan 49201, Korea

Tel: 82-51-240-5390, Fax: 82-51-247-7819

E-mail: jh57@dau.ac.kr

This is a thesis for a Master's degree by Sang Ho Lee.

Received: September 14, 2015.

Revised: 1st, December 16, 2015; 2nd, January 11, 2016;

3rd, February 1, 2016.

Accepted: February 5, 2016.

Korean J Anesthesiol 2016 June 69(3): 255-261

http://dx.doi.org/10.4097/kjae.2016.69.3.255

\section{Introduction}

Sore throat is common complication after surgery with tracheal intubation. It is said that postoperative sore throat (POST) is one of the outcomes that patients want to avoid after anesthesia. It adversely affects the satisfaction and activities of the patients after leaving hospital [1-3]. Incidence of sore throat is reported to range from $14.4 \%$ to $50.0 \%[4,5]$ and depends on various factors such as age, sex, the size and cuff pressure of the endotracheal tube, the duration for which the tube is in place, number of suctioning attempts, and the time and manipulations needed to insert the tube $[6,7]$.

(c) This is an open-access article distributed under the terms of the Creative Commons Attribution Non-Commercial License (http://creativecommons.org/ licenses/by-nc/4.0/), which permits unrestricted non-commercial use, distribution, and reproduction in any medium, provided the original work is properly cited. 
Dexamethasone is extensively used for the remedy of a sore throat arising from tracheal mechanical stimulation. It is a powerful glucocorticoid with anti-inflammatory and painkilling effects and anti-emetic properties [8-11]. It may have the potential for decreasing the incidence of POST during recovery, and the mechanism for this result is probably by modifying the inflammatory process caused by tissue injury [12-14].

The position change from supine to prone can make a change in endotracheal tube cuff pressure and endotracheal tube displacement $[15,16]$. The change in cuff pressure and tube displacement can affect the incidence of POST, hoarseness, and cough [6,7]. As previous studies only studied the effect of dexamethasone in supine position surgeries, this study investigated the prophylactic effect of dexamethasone in decreasing POST, hoarseness, and cough in prone position surgeries.

\section{Materials and Methods}

After we got approval from the Institutional Review Board for this study, written informed consent was obtained from all patients. One hundred-fifty patients aged between 18 to 75 years, American Society of Anesthesiologists (ASA) physical status IIII, requiring lumbar spine surgery under general anesthesia with endotracheal intubation were prospectively investigated.

Patients with a history of recent respiratory tract infection, prior medication with analgesics or corticosteroids were excluded. Other exclusion criteria included patients who had preoperative sore throat, hoarseness and cough, had a neuromuscular disease or had a nasogastric tube, had a duration of tracheal intubation of $<60 \mathrm{~min}$ or $>300 \mathrm{~min}$, and required more than one attempt for tracheal intubation.

Using a computer-generated random number table, the patients were randomly allocated into the normal saline group (placebo, group $\mathrm{P}, \mathrm{n}=50$ ), dexamethasone $0.1 \mathrm{mg} / \mathrm{kg}$ group (group D1, $\mathrm{n}=50$ ) or dexamethasone $0.2 \mathrm{mg} / \mathrm{kg}$ group (group $\mathrm{D} 2, \mathrm{n}=50$ ) before anesthesia induction. An anesthetic nurse, who was not taking part in postoperative patient interview and assessment, prepared the study drugs (dexamethasone or normal saline) as a $4 \mathrm{ml}$ clear solution in identical syringes and anesthesiologists were blinded to the syringe contents.

Patients were premedicated with intramuscular injection of $0.2 \mathrm{mg}$ of glycopyrrolate and intravenous injection of $50 \mathrm{mg}$ ranitidine. Non-invasive blood pressure, electrocardiography, pulse oximetry, and bispectral index were applied when the patients arrived in the operating room. The study drug was injected intravenously before anesthetic induction.

Anesthesia was induced with fentanyl $100 \mu \mathrm{g}$, propofol 2 $\mathrm{mg} / \mathrm{kg}$ and rocuronium $0.6 \mathrm{mg} / \mathrm{kg}$. We ventilated all patients with $100 \%$ oxygen via a facial mask. We performed tracheal intubation after confirming adequate muscle relaxation (the absence of movement and jaw relaxation). Endotracheal intubation was performed with tubes having an internal diameter of 8.0 or $7.5 \mathrm{~mm}$ for male patients, and 7.5 or $7.0 \mathrm{~mm}$ for female patients. After intubation, we inflated the tracheal tube cuff with room air at once and tuned the cuff pressure between 10 and 20 $\mathrm{cmH}_{2} \mathrm{O}$ using a cuff pressure manometer (Cuff Pressure Gauge; VBM Medizintechnik, DE). Patient's position was changed from supine to prone for surgery, and patient's head was positioned on the sponge face pillow without head rotation. After position change from supine to prone, we re-adjusted the cuff pressure between 10 and $20 \mathrm{cmH}_{2} \mathrm{O}$. All groups did not use humidifiers or heat and moisture exchangers. Anesthesia was maintained with $1.5-2.5$ vol\% sevoflurane and $50 \%$ in air. The end-tidal $\mathrm{CO}_{2}$ was kept between 35 and $40 \mathrm{mmHg}$.

When the surgeon began to suture the skin, an IV patientcontrolled analgesia (PCA) pump (GemStar ${ }^{\mathrm{TM}}$ Infusion System, Hospira, Inc., Lake Forest, IL, USA) containing fentanyl $30 \mu \mathrm{g} /$ $\mathrm{kg}$ and ramosetron $0.6 \mathrm{mg}$ in normal saline with total volume of $100 \mathrm{ml}$ was connected. This pump programmed to deliver $1 \mathrm{ml} /$ $\mathrm{h}$ as background infusion with a $1 \mathrm{ml}$ bolus at 10 min lockout period.

After the end of surgery, residual neuromuscular block was reversed with pyridostigmine $0.3 \mathrm{mg} / \mathrm{kg}$ and glycopyrrolate 0.01 $\mathrm{mg} / \mathrm{kg}$. Oral secretion was suctioned gently once. The endotracheal tube was removed when the patient was able to obey commands and lung ventilation was considered adequate.

Cricoid compression, duration of tracheal intubation, duration of prone position, duration of anesthetic time, and incidence of cough during extubation were recorded. The incidence

Table 1. Scoring System for Assessment of Sore Throat, Hoarseness and Cough

\begin{tabular}{cl}
\hline Severity score & \multicolumn{1}{c}{ Description } \\
\hline Sore throat & \\
0 & No sore throat at any time since the operation \\
1 & Minimal sore throat \\
2 & Moderate sore throat \\
3 & Severe sore throat \\
Hoarseness & No complaint of hoarseness \\
0 & Minimal change in quality of speech. \\
1 & (minimal hoarseness) \\
& Moderate change in quality of speech. \\
2 & (moderate hoarseness) \\
3 & (severe hoarseness) \\
Cough & No cough at any time since the operation \\
0 & Minimal cough \\
1 & Moderate cough \\
2 & Severe cough
\end{tabular}


and severity of POST, hoarseness, cough, and postoperative pain visual analog scale (VAS) were measured using direct interview by researcher who did not participate in this study at 1, 6, and 24 $\mathrm{h}$ after extubation. The severity of POST, hoarseness, and cough was graded using a 4-point scale (0: no, 1: minimal, 2: moderate, 3: severe) (Table 1) [13] Postoperative pain was assessed using a VAS $(0=$ no pain to $10=$ the most severe pain $)$.

The sample size was estimated from preliminary data obtained from 40 patients, and the assumption that a $20 \%$ reduction in the incidence of POST would be clinically relevant. The power analysis suggested that a minimum of 44 patients in each group would be needed for a $\beta=0.2, \alpha=0.05$, (adjusted Bonferroni's $\mathrm{p}$-value). To compensate for potential dropouts (drop rate $=10 \%), 50$ patients were enrolled in each group.

The results are expressed as the mean \pm SD or number of patients (\%). The demographic data and continuous data (duration of tracheal intubation, duration of prone position, and anesthetic duration) were analyzed using one-way ANOVA. Categorical data (gender, ASA status, size of endotracheal tube, external compression during intubation, cough during extubation, and incidence and severity of sore throat, hoarseness, and cough among the three groups) were analyzed by chi-square test. All follow-up analyses were corrected the Bonferroni adjustments. Values of $\mathrm{P}<0.05$ were considered statistically significant.

\section{Results}

Of the 150 enrolled patients, 3 patients were excluded from the analysis ( 1 in Group P and 2 in Group D1): three patients had an intubation time of more than 300 minutes (Fig. 1). The characteristics of these 147 patients are summarized in Table 2. There were no significant differences among the three groups with respect to age, weight, height, gender, ASA status. There were no significant differences in the duration of tracheal intubation and prone position, and the anesthetic time, and postoperative pain VAS score among the three groups. There were no significant differences in the size of endotracheal tube and external compression during intubation.

At 1, 6, and $24 \mathrm{~h}$ after extubation, the incidence of POST was significantly lower in group D1 ( $1 \mathrm{~h} ; 40 \%, \mathrm{P}=0.015$ / $6 \mathrm{~h} ; 17 \%$, $\mathrm{P}<0.001 / 24 \mathrm{~h} ; 4 \%, \mathrm{P}=0.038)$ and group D2 (1 h; 30\%, $\mathrm{P}<0.001$ / $6 \mathrm{~h} ; 4 \%, \mathrm{P}<0.001 / 24 \mathrm{~h} ; 2 \%, \mathrm{P}=0.017)$ compared to group $\mathrm{P}$ (1 h; 67\% / 6 h; 65\% / 24 h; 20\%) (Table 3).

The incidence of hoarseness at 1,6 , and $24 \mathrm{~h}$ after tracheal extubation was significantly lower in group D2 $(1 \mathrm{~h} ; 16 \%, \mathrm{P}=$ $0.001 / 6 \mathrm{~h} ; 8 \%, \mathrm{P}<0.001 / 24 \mathrm{~h} ; 0 \%, \mathrm{P}=0.001)$ than group $\mathrm{P}$ (1 h; 49\% / 6 h; 59\% / 24 h; 33\%) (Table 4).

There was no significant difference in the incidence of cough among the three groups (Table 5).

The incidence of severity scores of POST is described in

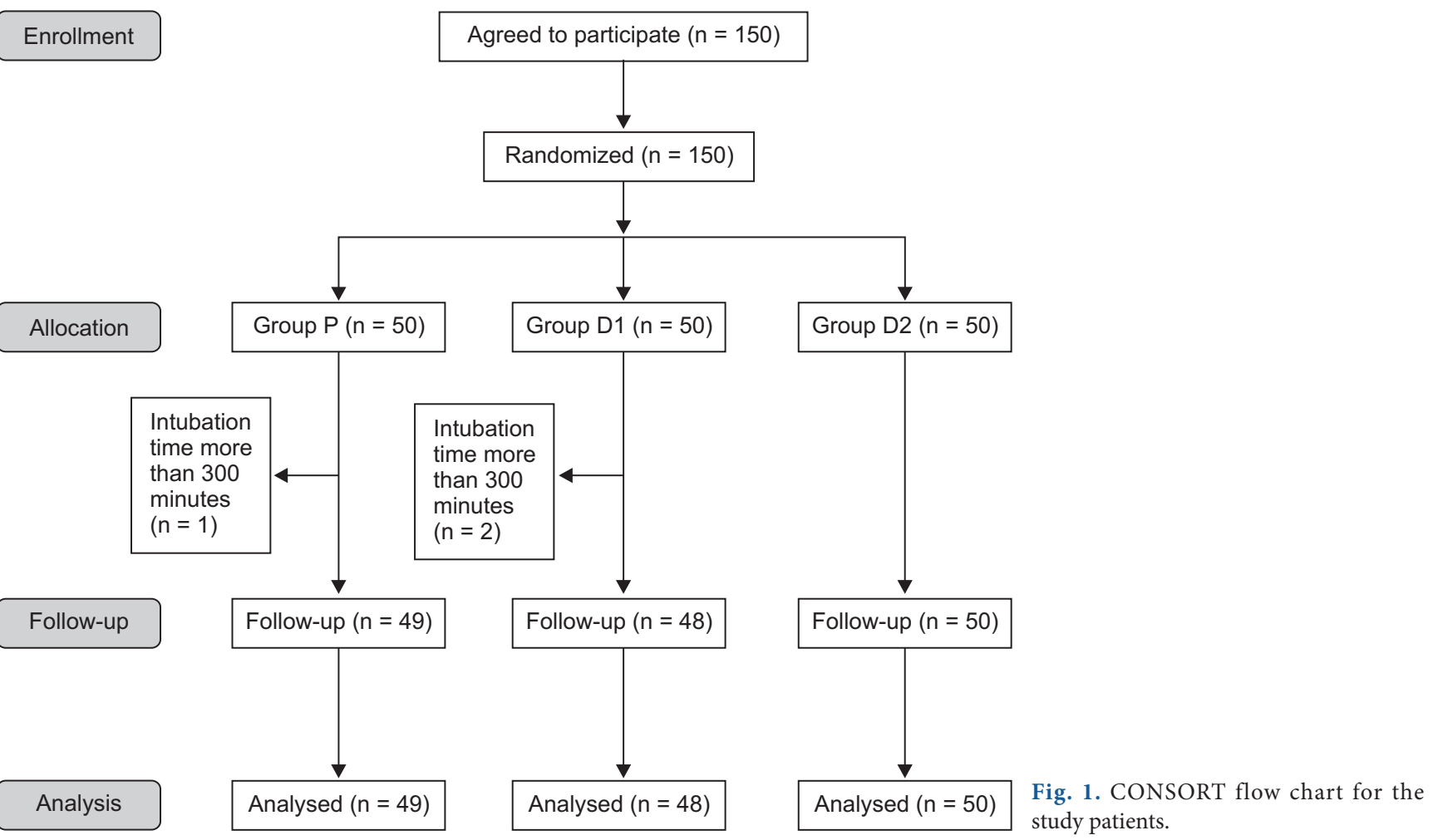


Table 2. Patient Characteristics

\begin{tabular}{|c|c|c|c|c|}
\hline & $\begin{array}{l}\text { Group P } \\
(\mathrm{n}=49)\end{array}$ & $\begin{array}{l}\text { Group D1 } \\
(\mathrm{n}=48)\end{array}$ & $\begin{array}{c}\text { Group D2 } \\
(\mathrm{n}=50)\end{array}$ & P value \\
\hline Age (yr) & $64.9 \pm 10.0$ & $61.9 \pm 16.0$ & $60.5 \pm 12.3$ & 0.238 \\
\hline Weight (kg) & $63.6 \pm 10.1$ & $62.9 \pm 12.1$ & $63.3 \pm 11.5$ & 0.953 \\
\hline Height $(\mathrm{cm})$ & $159.5 \pm 9.0$ & $160.8 \pm 10.4$ & $162.8 \pm 9.2$ & 0.224 \\
\hline $\operatorname{Sex}(M / F)$ & $18 / 31$ & $20 / 28$ & $20 / 30$ & 0.88 \\
\hline ASA class (I/II/III) & $3 / 25 / 21$ & $7 / 18 / 23$ & $3 / 26 / 21$ & 0.375 \\
\hline Size of endotracheal tube $(7 / 7.5 / 8)$ & $0 / 31 / 18$ & $2 / 26 / 20$ & $0 / 30 / 20$ & 0.328 \\
\hline External compression during intubation $(\mathrm{Y} / \mathrm{N})$ & $8 / 41$ & $13 / 35$ & $11 / 39$ & 0.438 \\
\hline Duration of tracheal intubation (min) & $156.6 \pm 44.5$ & $161.4 \pm 46.0$ & $143.1 \pm 37.0$ & 0.092 \\
\hline Duration of prone position (min) & $139.9 \pm 41.0$ & $146.0 \pm 45.1$ & $127.5 \pm 34.8$ & 0.073 \\
\hline Duration of anesthesia (min) & $164.4 \pm 44.5$ & $169.4 \pm 45.9$ & $150.8 \pm 36.8$ & 0.082 \\
\hline Cough during extubation & 3 & 5 & 4 & 0.741 \\
\hline \multicolumn{5}{|l|}{ Postoperative pain (VAS) } \\
\hline $1 \mathrm{~h}$ & $7.4 \pm 1.9$ & $7.3 \pm 2.2$ & $6.5 \pm 2.1$ & 0.053 \\
\hline $6 \mathrm{~h}$ & $5.9 \pm 2.1$ & $6.2 \pm 2.2$ & $5.6 \pm 2$ & 0.444 \\
\hline $24 \mathrm{~h}$ & $5.7 \pm 1.7$ & $6.1 \pm 2.4$ & $5.2 \pm 1.9$ & 0.089 \\
\hline
\end{tabular}

Values are expressed as mean \pm SD or number of patients. Group P: Placebo group, Group D1: Dexamethasone 0.1 mg/kg group, Group D2: Dexamethasone $0.2 \mathrm{mg} / \mathrm{kg}$ group.

Table 3. Incidences of Sore Throat among the Groups after Tracheal Extubation

\begin{tabular}{|c|c|c|c|c|c|c|c|}
\hline & \multirow{2}{*}{$\begin{array}{l}\text { Group P } \\
(\mathrm{n}=49)\end{array}$} & \multirow{2}{*}{$\begin{array}{c}\text { Group D1 } \\
(\mathrm{n}=48)\end{array}$} & \multirow{2}{*}{$\begin{array}{c}\text { Group D2 } \\
(\mathrm{n}=50)\end{array}$} & \multirow{2}{*}{$\mathrm{P}$ values } & \multicolumn{3}{|c|}{ Bonferroni's adjusted $\mathrm{P}$ value } \\
\hline & & & & & P vs. D1 & P vs. D2 & D1 vs. D2 \\
\hline $\begin{array}{c}1 \mathrm{~h} \\
(95 \% \mathrm{CI})\end{array}$ & $\begin{array}{c}33(67 \%) \\
(53.7-81.0)\end{array}$ & $\begin{array}{c}19(40 \%) \\
(25.2-53.9)\end{array}$ & $\begin{array}{c}15(30 \%) \\
(16.8-43.2)\end{array}$ & $<0.001$ & 0.015 & $<0.001$ & 1.000 \\
\hline $\begin{array}{c}6 \mathrm{~h} \\
(95 \% \mathrm{CI})\end{array}$ & $\begin{array}{c}32(65 \%) \\
(51.5-79.1)\end{array}$ & $\begin{array}{c}8(17 \%) \\
(5.7-27.6)\end{array}$ & $\begin{array}{c}2(4 \%) \\
(0.0-9.6)\end{array}$ & $<0.001$ & $<0.001$ & $<0.001$ & 1.000 \\
\hline $\begin{array}{c}24 \mathrm{~h} \\
(95 \% \mathrm{CI})\end{array}$ & $\begin{array}{c}10(20 \%) \\
(8.7-32.1)\end{array}$ & $\begin{array}{c}2(4 \%) \\
(0.0-10.0)\end{array}$ & $\begin{array}{c}1(2 \%) \\
(0.0-6.0)\end{array}$ & $<0.001$ & 0.038 & 0.017 & 1.000 \\
\hline
\end{tabular}

Values are number of patients (\%). Group P: Placebo group, Group D1: Dexamethasone $0.1 \mathrm{mg} / \mathrm{kg}$ group, Group D2: Dexamethasone $0.2 \mathrm{mg} / \mathrm{kg}$ group.

Table 4. Incidence of Hoarseness among the Groups after Tracheal Extubation

\begin{tabular}{|c|c|c|c|c|c|c|c|}
\hline & \multirow{2}{*}{$\begin{array}{l}\text { Group P } \\
(\mathrm{n}=49)\end{array}$} & \multirow{2}{*}{$\begin{array}{l}\text { Group D1 } \\
(\mathrm{n}=48)\end{array}$} & \multirow{2}{*}{$\begin{array}{c}\text { Group D2 } \\
(\mathrm{n}=50)\end{array}$} & \multirow{2}{*}{$\mathrm{P}$ values } & \multicolumn{3}{|c|}{ Bonferroni's adjusted $\mathrm{P}$ value } \\
\hline & & & & & P vs. D1 & P vs. D2 & D1 vs. D2 \\
\hline $1 \mathrm{~h}$ & $24(49 \%)$ & $13(27 \%)$ & $8(16 \%)$ & $<0.001$ & 0.211 & 0.001 & 1.000 \\
\hline$(95 \% \mathrm{CI})$ & $(34.5-63.5)$ & $(14.0-40.1)$ & $(5.5-26.5)$ & & & & \\
\hline $6 \mathrm{~h}$ & $29(59 \%)$ & $7(15 \%)$ & $4(8 \%)$ & $<0.001$ & $<0.001$ & $<0.001$ & 1.000 \\
\hline$(95 \% \mathrm{CI})$ & $(44.9-73.4)$ & $(4.2-24.9)$ & $(0.2-15.8)$ & & & & \\
\hline $24 \mathrm{~h}$ & $16(33 \%)$ & $5(10 \%)$ & $0(0 \%)$ & $<0.001$ & 0.186 & 0.001 & 1.000 \\
\hline (95\% CI) & $(19.0-46.3)$ & $(1.5-19.4)$ & $(-)$ & & & & \\
\hline
\end{tabular}

Values are number of patients (\%). Group P: Placebo group, Group D1: Dexamethasone $0.1 \mathrm{mg} / \mathrm{kg}$ group, Group D2: Dexamethasone $0.2 \mathrm{mg} / \mathrm{kg}$ group.

Table 6. There were less number of patients in the groups D1 and D2 than group P suffering from minimal grade of POST at $6 \mathrm{~h}$ after extubation and moderate grade of POST at 1, $24 \mathrm{~h}$ after extubation $(\mathrm{P}<0.05)$ (Table 6$)$. There was no significant difference in the incidence of severity scores of hoarseness and cough among the three groups.

\section{Discussion}

The result of this study showed that dexamethasone given before the induction of anesthesia decreased the incidence of POST and hoarseness (in group D2) at 1, 6, and $24 \mathrm{~h}$ after tracheal extubation compared with that in the group P. Less num- 
Table 5. Incidence of Cough among the Groups after Tracheal Extubation

\begin{tabular}{ccccc}
\hline & $\begin{array}{c}\text { Group P } \\
(\mathrm{n}=49)\end{array}$ & $\begin{array}{c}\text { Group D1 } \\
(\mathrm{n}=48)\end{array}$ & $\begin{array}{c}\text { Group D2 } \\
(\mathrm{n}=50)\end{array}$ & $\begin{array}{c}\text { P values } \\
\text { P vs. D1 vs. D2 }\end{array}$ \\
\hline $1 \mathrm{~h}$ & $5(10 \%)$ & $3(6 \%)$ & $0(0 \%)$ & 0.078 \\
$6 \mathrm{~h}$ & $2(4 \%)$ & $0(0 \%)$ & $1(2 \%)$ & 0.364 \\
$24 \mathrm{~h}$ & $4(8 \%)$ & $2(4 \%)$ & $0(0 \%)$ & 0.122 \\
\hline
\end{tabular}

Values are number of patients (\%). Group P: Placebo group, Group D1: Dexamethasone $0.1 \mathrm{mg} / \mathrm{kg}$ group, Group D2: Dexamethasone $0.2 \mathrm{mg} / \mathrm{kg}$ group.

Table 6. Severity Scores of Sore Throat after Extubation

\begin{tabular}{|c|c|c|c|c|c|c|c|}
\hline & \multirow{2}{*}{$\begin{array}{l}\text { Group P } \\
(\mathrm{n}=49)\end{array}$} & \multirow{2}{*}{$\begin{array}{l}\text { Group D1 } \\
(\mathrm{n}=48)\end{array}$} & \multirow{2}{*}{$\begin{array}{c}\text { Group D2 } \\
(\mathrm{n}=50)\end{array}$} & \multirow{2}{*}{$\mathrm{P}$ values } & \multicolumn{3}{|c|}{$\begin{array}{c}\text { Bonferroni's adjusted } \\
\text { P value }\end{array}$} \\
\hline & & & & & P vs. D1 & P vs. D2 & D1 vs. D2 \\
\hline \multicolumn{8}{|c|}{ At $1 \mathrm{~h}$} \\
\hline 1 & $17(35 \%)$ & $19(40 \%)$ & $13(26 \%)$ & 0.356 & 1.000 & 1.000 & 0.472 \\
\hline 2 & $13(27 \%)$ & $0(0 \%)$ & $2(4 \%)$ & $<0.001$ & $<0.001$ & $<0.001$ & 1.000 \\
\hline 3 & $3(6 \%)$ & $0(0 \%)$ & $0(0 \%)$ & 0.047 & 0.098 & 0.093 & 1.000 \\
\hline \multicolumn{8}{|c|}{ At $6 \mathrm{~h}$} \\
\hline 1 & $28(57 \%)$ & $7(14 \%)$ & $2(4 \%)$ & $<0.001$ & $<0.001$ & $<0.001$ & 0.483 \\
\hline 2 & $4(8 \%)$ & $1(2 \%)$ & $0(0 \%)$ & 0.068 & 0.294 & 0.076 & 1.000 \\
\hline 3 & 0 & 0 & 0 & - & - & - & - \\
\hline \multicolumn{8}{|c|}{ At $24 \mathrm{~h}$} \\
\hline 1 & $5(10 \%)$ & $2(4 \%)$ & $1(2 \%)$ & 0.180 & 0.574 & 0.221 & 1.000 \\
\hline 2 & $5(10 \%)$ & $0(0 \%)$ & $0(0 \%)$ & 0.005 & 0.015 & 0.014 & 1.000 \\
\hline 3 & 0 & 0 & 0 & - & & & \\
\hline
\end{tabular}

Values are number of patients (\%). Group P: Placebo group, Group D1: Dexamethasone $0.1 \mathrm{mg} / \mathrm{kg}$ group, Group D2: Dexamethasone $0.2 \mathrm{mg} / \mathrm{kg}$ group, 1: Minimal sore throat, 2: Moderate sore throat, 3: Severe sore throat.

ber of patients reported moderate grade of POST at 1, $24 \mathrm{~h}$ after extubation in groups D1 and D2 compared with group P.

Park et al. [17] reported that the prophylactic use of $0.1 \mathrm{mg} / \mathrm{kg}$ and $0.2 \mathrm{mg} / \mathrm{kg}$ of dexamethasone significantly decreased the incidence of sore throat at $1 \mathrm{~h}$ after extubation by $22 \%$ and $42 \%$, respectively, and dexamethasone $0.2 \mathrm{mg} / \mathrm{kg}$ decreased the incidence of sore throat at $24 \mathrm{~h}$ after extubation by $30 \%$. Bagchi et al. [13] found that the prophylactic intravenous dexamethasone in a dose of $0.2 \mathrm{mg} / \mathrm{kg}$ reduced the incidence of sore throat at $1 \mathrm{~h}$ after extubation by $30 \%$ and at $6 \mathrm{~h}$ after extubation by $24 \%$. Based on these previous studies, this study set the dose of dexamethasone in group D1 and group D2 as $0.1 \mathrm{mg} / \mathrm{kg}$ and $0.2 \mathrm{mg} / \mathrm{kg}$, respectively.

The factors which are known to affect the prevalence of postoperative sore throat include difficult intubation procedure or repeated attempts, larger diameter of the tracheal tube, displacement of the endotracheal tube during the surgery, bucking on the tube, and excessive oral suctioning during extubation [18]. The pathological cause of sore throat is thought to be an aseptic inflammatory process because of the irritation of the pharyngeal mucosa during laryngoscopy, the damage of tracheal mucosa by the cuff of the endotracheal tube, and the trauma to tissues dur- ing the processes of intubation and extubation $[17,19,20]$.

Postoperative hoarseness is the result of at least some degree of laryngeal injury. Several risk factors for laryngeal injury and postoperative hoarseness have been identified, including endotracheal tube size, cuff design, cuff pressure, movement of the tube, physical trauma, duration of intubation as well as demographic factors such as sex or even the type of surgery [21].

The prophylactic use of steroids reduced the incidence of sore throat and hoarseness during recovery, probably by modifying the inflammatory process caused by tissue injury. This antiinflammatory process includes inhibition of leukocyte migration to the site of inflammation and inhibition of release of cytokines probably by maintaining cellular integrity. Fibroblast proliferation may also be inhibited $[17,18,20,22]$. Dexamethasone can reduce the synthesis of inflammatory mediators, prostaglandins, and leukotrienes by inhibiting phospholipase $\mathrm{A}_{2}$ through production of calcium-dependent phospholipid-binding proteins called annexins [23] and by inhibition of cyclooxygenase 2 during inflammation [24].

Potential side effects of dexamethasone include increased susceptibility of infection, hyperglycemia, delayed wound healing, adrenal suppression, and a vascular necrosis of the hip or 
other joints. Although a single dose of dexamethasone is considered safe, further studies with longer follow-ups are required [25].

The position change from supine to prone can cause the change of cuff pressure and the displacement of endotracheal tube [16]. In a recent study, endotracheal tube displacement was occurred in $91.7 \%$ of patients after the supine-to-prone position change; of these, $48 \%$ of patients' endotracheal tube moved more than $10 \mathrm{~mm}$ and endotracheal tube cuff pressure was changed in $86.3 \%$ of patients [15]. The changes in cuff pressure and tube displacement are the factors that affect the incidence of POST, hoarseness, and cough [6,7]. Therefore, higher incidence and severity of POST, hoarseness, and cough were expected in prone position surgery compared with supine position surgery.

In this study, the incidence of POST in the group $\mathrm{P}$ was 67 and $65 \%$ at 1 and $6 \mathrm{~h}$ after tracheal extubation, respectively. These incidence figures are somewhat higher than those in previous reports $[13,14]$ of supine surgery patients. The incidence of hoarseness in the group $\mathrm{P}$ after extubation was also higher than that in the other study $[13,14]$. In this study, the change in patient position was performed two times in order to achieve the prone position and recovery of anesthesia at termination of surgery. In addition, prone position was maintained during the operation. These factors might be thought to contribute the incidence of sore throat and hoarseness. However, there were the difference of intubation time between this study and the other studies $[13,14]$. Therefore, many studies would be required to find out the relationship between prone position and POST.

The limitation of this study was that the fiberoptic bronchoscope was not used to assess tissue damage and displacement of endotracheal tube. Sore throat, hoarseness, and cough could not be assessed objectively, and there were inter-individual variations; therefore, a chance of bias exists. This study was not designed to perform an additional follow-up beyond $24 \mathrm{~h}$ as the process of acute inflammation usually peaks by $24 \mathrm{~h}$.

In conclusion, prophylactic intravenous dexamethasone 0.1 and $0.2 \mathrm{mg} / \mathrm{kg}$ significantly reduced the incidence of postoperative sore throat and dexamethasone $0.2 \mathrm{mg} / \mathrm{kg}$ decreased the incidence of hoarseness in patients undergoing prone position surgery.

\section{Acknowledgments}

This study was supported by research funds from Dong-A University.

\section{References}

1. Higgins PP, Chung F, Mezei G. Postoperative sore throat after ambulatory surgery. Br J Anaesth 2002; 88: 582-4.

2. Macario A, Weinger M, Truong P, Lee M. Which clinical anesthesia outcomes are both common and important to avoid? The perspective of a panel of expert anesthesiologists. Anesth Analg 1999; 88: 1085-91.

3. Estebe JP, Dollo G, Le Corre P, Le Naoures A, Chevanne F, Le Verge R, et al. Alkalinization of intracuff lidocaine improves endotracheal tube-induced emergence phenomena. Anesth Analg 2002; 94: 227-30.

4. Christensen AM, Willemoes-Larsen H, Lundby L, Jakobsen KB. Postoperative throat complaints after tracheal intubation. Br J Anaesth 1994; 73: 786-7.

5. Maruyama K, Sakai H, Miyazawa H, Toda N, Inuma Y, Mochizuki N, et al. Sore throat and hoarseness after total intravenous anaesthesia. Br J Anaesth 2004; 92: 541-3.

6. Mandøe H, Nikolajsen L, Lintrup U, Jepsen D, Mølgaard J. Sore throat after endotracheal intubation. Anesth Analg 1992; 74: 897-900.

7. McHardy FE, Chung F. Postoperative sore throat: cause, prevention and treatment. Anaesthesia 1999; 54: 444-53.

8. Baxendale BR, Vater M, Lavery KM. Dexamethasone reduces pain and swelling following extraction of third molar teeth. Anaesthesia 1993; 48: $961-4$

9. Elhakim M, Ali NM, Rashed I, Riad MK, Refat M. Dexamethasone reduces postoperative vomiting and pain after pediatric tonsillectomy. Can J Anaesth 2003; 50: 392-7.

10. Schmelzeisen R, Frölich JC. Prevention of postoperative swelling and pain by dexamethasone after operative removal of impacted third molar teeth. Eur J Clin Pharmacol 1993; 44: 275-7.

11. Wang JJ, Ho ST, Lee SC, Liu YC, Liu YH, Liao YC. The prophylactic effect of dexamethasone on postoperative nausea and vomiting in women undergoing thyroidectomy: a comparison of droperidol with saline. Anesth Analg 1999; 89: 200-3.

12. Ruangsin S, Wanasuwannakul T, Pattaravit N, Asim W. Effectiveness of a preoperative single dose intravenous dexamethasone in reducing the prevalence of postoperative sore throat after endotracheal intubation. J Med Assoc Thai 2012; 95: 657-60.

13. Bagchi D, Mandal MC, Das S, Sahoo T, Basu SR, Sarkar S. Efficacy of intravenous dexamethasone to reduce incidence of postoperative sore throat: A prospective randomized controlled trial. J Anaesthesiol Clin Pharmacol 2012; 28: 477-80.

14. Thomas S, Beevi S. Dexamethasone reduces the severity of postoperative sore throat. Can J Anaesth 2007; 54: 897-901.

15. Minonishi T, Kinoshita H, Hirayama M, Kawahito S, Azma T, Hatakeyama N, et al. The supine-to-prone position change induces 
modification of endotracheal tube cuff pressure accompanied by tube displacement. J Clin Anesth 2013; 25: 28-31.

16. Kim D, Jeon B, Son JS, Lee JR, Ko S, Lim H. The changes of endotracheal tube cuff pressure by the position changes from supine to prone and the flexion and extension of head. Korean J Anesthesiol 2015; 68: 27-31.

17. Park SH, Han SH, Do SH, Kim JW, Rhee KY, Kim JH. Prophylactic dexamethasone decreases the incidence of sore throat and hoarseness after tracheal extubation with a double-lumen endobronchial tube. Anesth Analg 2008; 107: 1814-8.

18. Scuderi PE. Postoperative sore throat: more answers than questions. Anesth Analg 2010; 111: 831-2.

19. Huang YS, Hung NK, Lee MS, Kuo CP, Yu JC, Huang GS, et al. The effectiveness of benzydamine hydrochloride spraying on the endotracheal tube cuff or oral mucosa for postoperative sore throat. Anesth Analg 2010; 111: 887-91.

20. Canbay O, Celebi N, Sahin A, Celiker V, Ozgen S, Aypar U. Ketamine gargle for attenuating postoperative sore throat. Br J Anaesth 2008; 100: 490-3.

21. Mencke T, Echternach M, Kleinschmidt S, Lux P, Barth V, Plinkert PK, et al. Laryngeal morbidity and quality of tracheal intubation: a randomized controlled trial. Anesthesiology 2003; 98: 1049-56.

22. Liu J, Zhang X, Gong W, Li S, Wang F, Fu S, et al. Correlations between controlled endotracheal tube cuff pressure and postprocedural complications: a multicenter study. Anesth Analg 2010; 111: 1133-7.

23. Yao XL, Cowan MJ, Gladwin MT, Lawrence MM, Angus CW, Shelhamer JH. Dexamethasone alters arachidonate release from human epithelial cells by induction of p11 protein synthesis and inhibition of phospholipase A2 activity. J Biol Chem 1999; 274: $17202-8$.

24. Lubenow TR, Ivankovich D, McCarthy RJ. Management of acute postoperative pain. In: Clinical Anesthesia. Edited by Barash PG, Cullen BF, Stoelting RK: Philadelphia, Lippincott Williams \& Wilkins Inc. 2001, pp 1403-34.

25. Elhakim M, Ali NM, Rashed I, Riad MK, Refat M. Dexamethasone reduces postoperative vomiting and pain after pediatric tonsillectomy. Can J Anaesth 2003; 50: 392-7. 